\title{
Diet and histological features of digestive tube from four discarded fish species by trawl bycatch in Northeastern Brazil
}

\author{
Aline da Costa Bomfim ${ }^{1,2,3} * \oplus^{\infty}$, Daniel Solon Dias Farias ${ }^{1,2,3}$, Hamilton Barroso Mourão-Junior ${ }^{1,2}$, Iara Cecília da \\ Costa Morais $^{1,2}$, Silmara Rossi ${ }^{1}$, Simone Almeida Gavilan ${ }^{1,2}$ \& Flávio José de Lima Silva ${ }^{2,4}$ \\ ${ }^{1}$ Universidade Federal do Rio Grande do Norte, Centro de Biociências, Departamento de Morfologia, \\ Laboratório de Morfofisiologia de Vertebrados, Campus Universitário UFRN, Avenida Senador Salgado Filho, \\ 3000, Lagoa Nova, CEP 59078-900, Natal, RN, Brasil. \\ ${ }^{2}$ Universidade do Estado do Rio Grande do Norte, Laboratório de Monitoramento de Biota Marinha, Campus \\ Central, CEP 59600-000, Mossoró, RN, Brasil. \\ ${ }^{3}$ Universidade Federal do Rio Grande do Norte, Programa de Doutorado em Desenvolvimento e Meio \\ Ambiente - DDMA, Campus Universitário UFRN, Lagoa Nova, CEP 59072-970, Natal, RN, Brasil. \\ ${ }^{4}$ Universidade do Estado do Rio Grande do Norte, Departamento de Turismo, Campus Natal, Av Dr. João \\ Medeiros Filho, 3419, Potengi (Zona Norte), CEP 59104-200, Natal, RN, Brasil.
}

*Corresponding author: Aline da Costa Bomfim, e-mail: alinebonfim_7@hotmail.com

BOMFIM, A.C., FARIAS, D.S.D., MOURÃO-JUNIOR, H.B., MORAIS, I.C.C., ROSSI, S., GAVILAN, S.A., SILVA, F.J.L. Diet and histological features of digestive tube from four discarded fish species by trawl bycatch in Northeastern Brazil. Biota Neotropica 20(3): e20200951. https://doi.org/10.1590/1676-0611-BN-2020-0951

\begin{abstract}
Fish feeding habit associated to the morphology of their digestive tube can provide useful biological and ecological information. Between January and December 2012, we examined 16 fish species discarded by trawl in the Potiguar basin, northeastern Brazil, and classified them into four groups according to Alimentary Index - IAi. Our aims were to: (1) provide information on diet composition of one species represented by each group (Opisthonema oglinum, Conodon nobilis, Larimus breviceps and Sphoeroides testudineus), (2) examine the morphology of their digestive tube, and (3) associate ingested food items with the morphological features. Stomach contents were collected and classified according to IAi: main, accessory and secondary categories; fragments of esophagus, stomach, and small intestine were examined using paraffin section technique. Biometric data (total length-TL, standard length-SL and total weight-TW), stomach weight-SW, and gonadal weight-GW were recorded and applied in two indices: (1) the stomach Repletion Index - SRI (SRI $=$ SW/TW $\times 100)$ and (2) the gonadosomatic index - GSI $($ GSI $=$ GW/TW $\times 100)$ for the analyses of feeding and reproductive activities, respectively. The main food categories were (1) Teleostei for C. nobilis, (2) Crustacea for L. breviceps and O. oglinum, and (3) Mollusca for $\mathrm{S}$. testudineus. The feeding activity was higher during the dry season, while the GSI was higher in the rainy season. The morphological analysis revealed a regular structure of the tissues analyzed. We highlight the presence of tubular gastric glands and strong muscular walls in the stomach (O. oglinum; L. breviceps); well-developed pyloric caecum in the intestine (O. oglinum; C. nobilis; L. breviceps); and presence of pseudo-stomach (S. testudineus). Our study confirms that the digestive tube of the examined species has morphological adequacy for carnivorous feeding habit, providing useful information on tissue structures associated to diet composition.
\end{abstract}

Keywords: feeding ecology; fish; histology; feeding activity.

\section{Dieta e características histológicas do tubo digestivo de quatro espécies de peixes descartadas pela pesca de arrasto no nordeste do Brasil}

Resumo: O hábito alimentar de peixes associado à morfologia do tubo digestivo pode fornecer informações biológicas e ecológicas úteis. Entre janeiro e dezembro de 2012, examinamos 16 espécies de peixes descartadas por pesca de arrasto na Bacia Potiguar, nordeste do Brasil, e as classificamos em quatro grupos, de acordo com o Índice AlimentarIAi. Nossos objetivos foram: (1) fornecer informações sobre a composição da dieta de uma espécie representante de cada grupo (Opisthonema oglinum, Conodon nobilis, Larimus breviceps e Sphoeroides testudineus), (2) examinar a morfologia de seu tubo digestivo e (3) associar os itens alimentares ingeridos com as características morfológicas descritas. O conteúdo estomacal foi coletado e classificado de acordo com o IAi nas categorias: principal, acessória e secundária; fragmentos de esôfago, estômago e intestino delgado foram examinados pela técnica de secção em parafina. 
Os dados biométricos (comprimento total-CT, comprimento padrão-CP e peso total-PT), peso do estômago-PE e peso gonadal-PG foram registrados e aplicados em dois índices: (1) Índice de Repleção Estomacal - IR (IR = $\mathrm{PE} / \mathrm{PT} \times 100)$ e (2) Índice Gonadossomático - IGS $(\mathrm{IGS}=\mathrm{PG} / \mathrm{PT} \times 100)$ para análises de atividade alimentar e reprodutiva, respectivamente. As principais categorias alimentares foram: (1) Teleostei para C. nobilis, (2) Crustacea para L. breviceps e O. oglinum, e (3) Mollusca para S. testudineus. Maior atividade alimentar ocorreu durante a estação seca, e o IGS foi maior na estação chuvosa. O exame morfológico revelou estrutura regular dos tecidos analisados, destacando-se a presença de glândulas gástricas tubulares e camadas musculares espessas no estômago (O. oglinum; L. breviceps); cecos pilóricos bem desenvolvidos no intestino (O. oglinum; C. nobilis; L. breviceps); e presença de pseudoestômago (S. testudineus). Nosso estudo confirma que o tubo digestivo das espécies examinadas possui adequação morfológica ao hábito alimentar carnívoro e fornece informações úteis sobre as estruturas dos tecidos associados à composição da dieta.

Palavras-chave: ecologia alimentar; peixe; histologia; atividade alimentar.

\section{Introduction}

The coast in Rio Grande do Norte State, Brazil, stretches over approximately $400 \mathrm{~km}$, and is characterized by significant fishing activity with $76.5 \%$ represented by artisanal fisheries (Ibama 2010). Thus, the discard of trawl fishing is concerning and relevant for marine conservation (Helfman et al. 2009). Fish bycatch is often higher than capture of target species, especially in multi-target small-scale fisheries operating in the northwestern coast of Rio Grande do Norte (Silva-Júnior et al. 2013). In this region, trawl fisheries conducted by small boats aim to capture shrimp; however, many fish are accidentally captured (Bomfim et al. 2019).

Over the last decades, concerns about bycatch of charismatic species such as dolphins and marine turtles have increased and quickly expanded to other species (e.g. juvenile fish discarded by bottom trawls) (Kennelly \& Broadhurst 2002, Burgess et al. 2018). Bycatch of juvenile animals influences their conservation and affect density and distribution of predators, resulting in a limited abundance and distribution (Block et al. 2011, Stewart \& Jones 2001).

Fishes feed on various resources at different water depths and studies on digestive tube descriptions provide useful biological and ecological information on environmental factors and food availability (Canan et al. 2012). Aspects of the digestive tube morphology have been described in several fish species, increasing the interest on their morphological variation, diet, and behavior (as a result from trophic levels in the food web and the high ichthyofaunal diversity) (Vieira-Lopes et al. 2013). However, few studies have investigated anatomical and histological aspects of neotropical ichthyofaunal digestive tube (Canan et al. 2012). The analyses of feeding habits and morphology features provide knowledge on food dynamics (e.g. intra- and inter-specific interactions and community energy flux) and habitat use (Hajisamaea et al. 2003; Cachera et al. 2017).

Most tropical fishes have an intense trophic plasticity and varied diet, which may be related to spatial, seasonal, ontogenetic, and behavioral factors, providing more advantages to generalist than to specialist species (Lowe-McConnell 1999, Abelha et al. 2001). We examined and classified 16 fish species into four groups, according to Alimentary Index (IAi), discarded by trawls in the study site. Our study aimed to (1) provide information on diet composition of one species represented by each group (Opisthonema oglinum, Conodon nobilis, Larimus breviceps and Sphoeroides testudineus), (2) examine the morphology of their digestive tube, and (3) associate ingested food items to morphological features.

\section{Materials and Methods}

\section{Study site}

This study was carried out in northeastern Brazil, between the municipalities of Caiçara do Norte (5 ${ }^{\circ} 4^{\prime} 1.15^{\text {"S }, 36}{ }^{\circ} 4$ '36 .41" W), Rio Grande do Norte State (RN), and Icapui (4³8'48.28”'S and $\left.37^{\circ} 32^{\prime} 52.08^{\prime \prime} \mathrm{W}\right)$, Ceará State (CE), a region known as the Potiguar Basin, which stretches over approximately $300 \mathrm{~km}$ (Figure 1). The study site is formed by crystalline basement rocks (Soares et al. 2003), with different geomorphological and environmental characteristics along the extension monitored. In Icapuí, tourism, artisanal fishing, and saliniculture are the main economic activities, while in Caiçara do Norte, artisanal or professional fishing (depending on the beach), wind energy, and gas/petroleum exploration are the local economic activities. The climate in the region is semi-arid with varied humidity, low rainfall, and two well-defined seasons: dry (between August and December), with strong winds, and rainy (from January to July) (Jimenez et al. 1999, Testa \& Bosence 1999).

Since 2010, the Projeto Cetáceos da Costa Branca - Universidade do Estado do Rio Grande do Norte (PCCB-UERN) has conducted the Beach Monitoring Program in the Potiguar Basin (Programa de Monitoramento de Praias da Bacia Potiguar - PMP-BP). The PMP$\mathrm{BP}$ is part of an environmental constraint compliance enforced by the Instituto Brasileiro do Meio Ambiente e dos Recursos Naturais Renováveis - IBAMA (Brazilian Institute of the Environment and Renewable Natural Resources) for oil exploration by PETROBRAS (Petróleo Brasileiro S.A.; agreement number 2500.005657510.2).

\section{Sampling}

Between January and December 2012, samples were collected monthly during daily monitoring conducted by a trained field team using a four-wheeled (i.e. quad) motorcycle and a portable GPS, and prior approaches with fishermen at the time of drag. Trawl nets varied from 6 to $40 \mathrm{~m}$ long X $3 \mathrm{~m}$ wide, and were usually made of mono or braided nylon (also named "trammel"). Fishermen often use this type of trawl net to capture shrimp during the day, at an average depth of $1.5 \mathrm{~m}$; however, other animals are also caught by the net.

The individuals collected were stored in isothermal bags and transported to the support base, where they were photographed, fixed in $10 \%$ formalin, and preserved in $70 \%$ alcohol for further identification by experts and according to previous studies (Menezes \& Figueiredo 
2000, Szpilman 2000, Júnior et al. 2010). We evaluated total lengthTL, standard length-SL, total weight-TW, stomach weight-SW, and gonadal weight-GW.

\section{Diet analyses}

The stomach contents were preserved in $70 \%$ alcohol and the analyses combined three methods: (1) Points method: visual estimate of volume percentage of each food item. Different classes were given a number of points and the sums of points for each food item were reduced to percentages to show the percentage of diet composition (Swynnerton \& Worthington 1940). (2) Frequency of occurrence (F\%): number of stomachs containing one or more individuals of each food category was expressed as a percentage of all stomachs containing food (Dineen 1951, Dunn 1954, Kennedy \& Fitzmaurice 1972). (3) Volumetric method by direct estimation (V\%): the measurement of each food item or group of items sorted from the stomach contents was performed in a graduated measuring device, according to Wolfert \& Miller (1978), considering the volume of each food item and expressed as percentage of all food item (Kawakami \& Vazzoler 1980). Microscopic items were analyzed through slides prepared with the homogenized food contents.

Alimentary Index (Índice Alimentar - IAi) (Kawakami \& Vazzoler 1980) was applied for each food item: IAi= Fi x Vi/ $\sum \mathrm{n}(\mathrm{Fi} \times \mathrm{Vi})$; whereas $\mathrm{F}=$ Frequency of occurrence $(\%)$ of each item, and $\mathrm{V}=$ Volume $(\%)$ of each item, and $i=1,2, \ldots n=$ determined food item. In order to analyze the diet composition considering the IAi, food items found were classified into categories according to Rosecchi \& Nouaze (1987): IAi $<0.25$ (accessory category), $0.25 \leq \mathrm{IAi}<0.5$ (secondary category), and $\mathrm{IAi} \geq 0.5$ (main category).

\section{Feeding and reproductive activities}

Feeding and reproductive activities were analyzed considering the rainy and dry seasons. Climatic, geomorphologic, phytogeographic, and tectonic differences can influence wind direction and ocean circulation pattern (Vital 2006), changing food availability and fish reproductive behavior. The data on precipitation for the study period was obtained from Proclima (Real-Time Climate Monitoring Program for the Northeast) (http://www6.cptec.inpe.br/proclima/ accessed in January $31^{\text {st }} 2013$ ).

The feeding activity was calculated using the Stomach Repletion Index $(\mathrm{SRI}): \mathrm{SRI}=\mathrm{SW} / \mathrm{TW} \times 100$ that provides information on the influence of spatial-temporal variation in the feeding activity (Stricta-Pereira et al. 2010).

The gonadosomatic index (GSI) was used to determine the reproductive activity: $\mathrm{GSI}=\mathrm{GW} / \mathrm{TW} \times 100$, which is an indicator of gonadal functional status (Maddock \& Burton 1999, Wootton et al. 1978).

\section{Tissue processing}

Samples of the digestive tube were obtained during postmortem examination, fixed in 10\% formalin, dehydrated, diaphanized, and embedded in paraffin. Serial $5 \mu \mathrm{m}$ sections were prepared and stained with hematoxylin and eosin (HE).

\section{Statistical analyses}

The Cluster analysis, considering Euclidean distance as a measure, was performed to evaluate similarity among fish species according to types of food items found in their stomach contents. The Wards method was applied to organize the variables into four groups. The dendrogram generated from similarity of ingested food items was used to analyze the relation of morphohistologic features of the digestive tube with food habit for one species from each group.

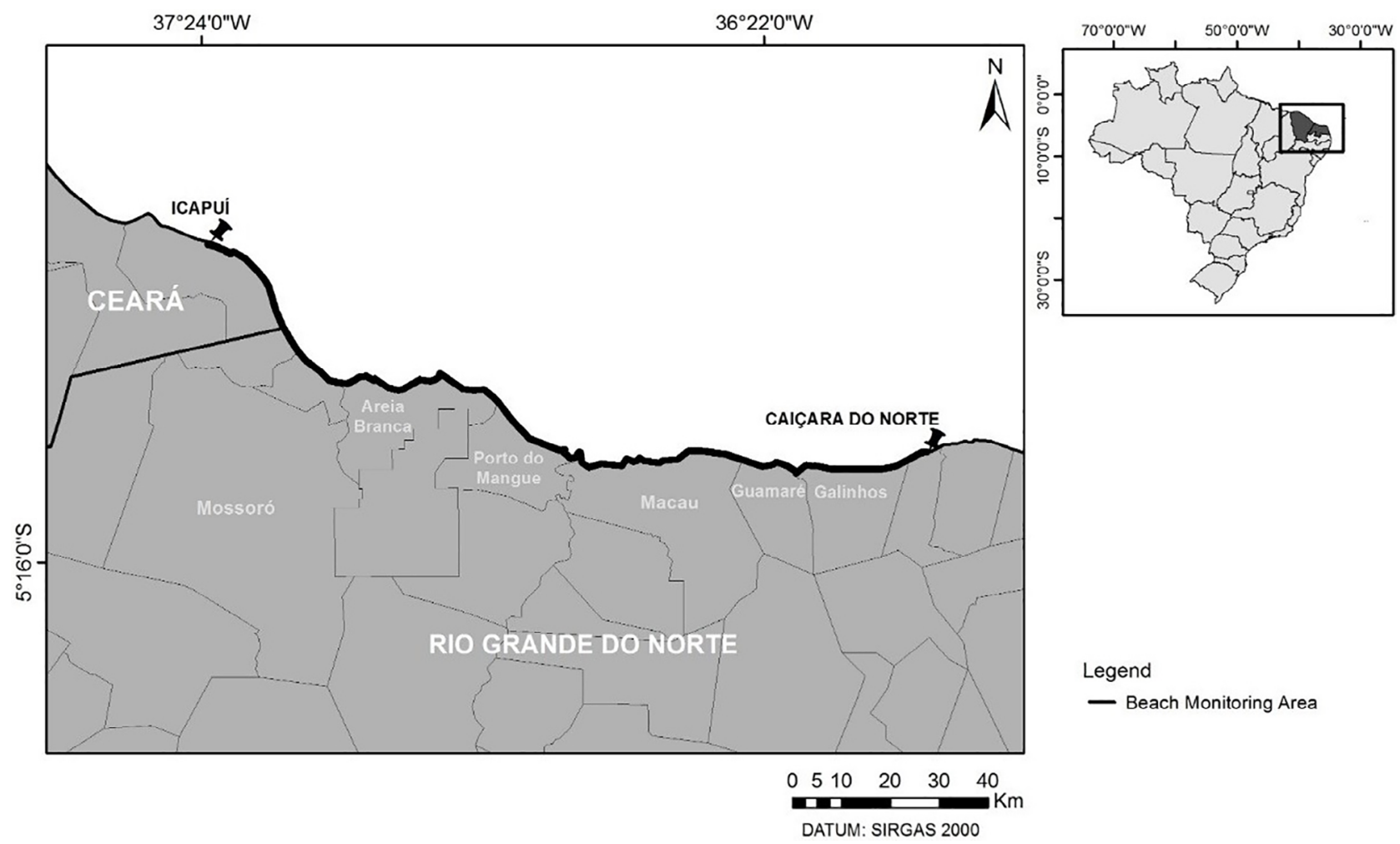

Figure 1. Geographic distribution of the study site, Brazilian northeastern coast. Source: Projeto Cetáceos da Costa Branca - Universidade do Estado do Rio Grande do Norte (PCCB-UERN). 


\section{Results}

We examined and classified 1,232 individuals into five orders, 11 families, and 16 species. Pomadasys corvinaeformis $(\mathrm{n}=423 ; 34.33 \%$; Roughneck grunt; Perciformes: Pomadasyidae), Opisthonema oglinum ( $\mathrm{n}=136 ; 11.04 \%$; Atlantic thread herring; Clupeiformes: Clupeidae) and Larimus breviceps $(\mathrm{n}=129 ; 10.47 \%$; Shorthead drum; Perciformes: Sciaenidae) represented more than $50 \%$ of individuals captured, followed by Menticirrhus littoralis $(\mathrm{n}=98 ; 7.95 \%$; Gulf kingcroacker; Perciformes: Sciaenidae), Conodon nobilis ( $\mathrm{n}=93 ; 7.55 \%$; Barred grunt; Perciformes: Haemulidae), Pelona harroweri ( $\mathrm{n}=70 ; 5.68 \%$; American coastal pellona; Clupeiformes: Pristigasteridae), Lycengraulis grossidens ( $\mathrm{n}=52 ; 4.22 \%$; Atlantic sabretooth anchovy; Clupeiformes: Engraulidae), Selene brownii $(\mathrm{n}=51 ; 4.14 \%$; Caribbean moonfish; Perciformes: Carangidae), Aspistor luniscutis ( $\mathrm{n}=50 ; 4.06 \%$; Sea catfish; Siluriformes: Ariidae), Bagre marinus ( $\mathrm{n}=40 ; 3.25 \%$; Gafftopsail sea catfish; Siluriformes: Ariidae), Sphoeroides testudineus ( $\mathrm{n}=34 ; 2.76 \%$; Checkered puffer; Tetraodontiformes: Tetraodontidae), Polydactylus virginicus ( $\mathrm{n}=28 ; 2.27 \%$; Barbu; Perciformes: Polynemidae), Bagre bagre $(\mathrm{n}=11 ; 0.89 \%$; Coco sea catfish; Siluriformes: Ariidae), Gymnura micrura $(\mathrm{n}=8 ; 0.65 \%$; Smooth butterfly ray; Myliobatiformes: Gymnuridae), Lagocephalus laevigatus ( $\mathrm{n}=5 ; 0.41 \%$; Smooth puffer; Tetraodontiformes: Tetraodontidae), and Dasyatis guttata ( $\mathrm{n}=4 ; 0.32 \%$; Longnose stingray: Myliobatiformes: Dasyatidae).

\section{Diet composition}

We analyzed the diet of 16 species discarded by trawl, which were classified into four groups, according to IAi: (I) Group represented by species with 'Crustacea' as the main food category, 'Sediment' as secondary or accessory category: L. grossidens and O. oglinum; (II) Group represented by species with 'Teleostei' as the main food category: C. nobilis, B. bagre, B. marinus and G. micrura; (III) Group represented by species with 'Crustacea' as the main food category, 'Teleostei' as secondary or accessory category: P. virginicus, M. littoralis, S. brownii, D. guttata, L. breviceps, $P$. harroweri, A. luniscutis and $P$. corvinaeformis; and (IV) Group represented by species with 'Mollusca' as the main food category and 'Echinodermata' as accessory category: L. laevigatus and S. testudineus (Figure 2).

Stomach contents from 222 individuals of four species representing each group were fully analyzed: group $\mathrm{I}-O$ oglinum $(\mathrm{n}=85)$; group II $-C$. nobilis $(\mathrm{n}=51)$; group III - L. breviceps $(\mathrm{n}=67)$, and group IV - S. testudineus $(\mathrm{n}=19)$. In addition, we analyzed stomach contents of $M$. littoralis $(\mathrm{n}=33)$ and $P$. corvinaeformis $(\mathrm{n}=52)$, species most discarded by trawl, along with $C$. nobilis and L. breviceps.

Food items were found and classified into 15 categories: (1) Nematoda, (2) Cnidaria, (3) Mollusca, (4) Polychaeta, (5) Crustacea, (6) Insecta, (7) Echinodermata, and (8) Teleostei (Animal categories); (9) Algae; (10) Vegetal matters and (11) Animal matters (semi digested material); (12) Sediment; (13) Rocks; (14) Plastic matters and (15) Non-identified items (due to advanced digestion stage of food items).

O. oglinum had the higher number of food items $(\mathrm{n}=27)$. Gastrophoda (Mollusca category) represented the higher frequency of occurrence (40\%), followed by Dendrobranchiata (Crustacea category) (25.882353\%), sediment (20\%) and Cirripedia (Crustacea category) (20\%). According to the IAi, Crustacea represented the main food category (0.509717). Sediment was classified as secondary category (0.252846), and Mollusca had the highest value of all accessory categories (0.201009) (Table 1).

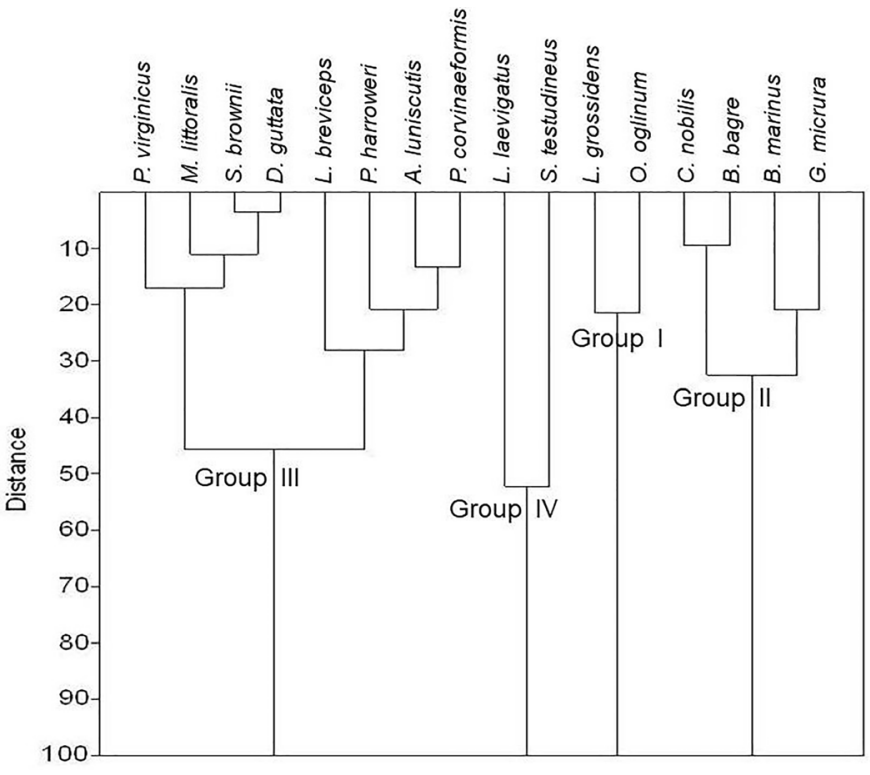

Figure 2. Dendogram of 16 species discarded by trawl in northeastern Brazil between January and December 2012, based on similarity of ingested food items.

C. nobilis: whole fish (Teleostei category) represented the highest frequency of occurrence $(76.470548 \%)$, followed by Dendrobranchiata (19.607843\%). Fourteen food items were described, and the Teleostei represented the main food category $(\mathrm{IAi}=0.877130)$. Crustacea, Animal matters, Vegetal matters, and Mollusca were considered accessory categories, and Crustacea presented the highest value $(0.111814)$ (Table 1).

M. littoralis: Dendrobranchiata was the item with the highest frequency of occurrence (57.575758\%), followed by Animal matters (30.303030\%). Twelve food items were described, and according to the IAi, Crustacea category (0.698015) mainly composed the diet. Although Animal matters, Polychaeta, Mollusca, Teleostei, and Cnidaria were all considered accessory categories, Animal matters represented the highest index (0.146784), followed by Polychaeta (0.118038) (Table 1).

L. breviceps had 15 food items described, with Dendrobranchiata representing the highest frequency of occurrence $(77.611940 \%)$, followed by fry $(28.358209 \%)$, and rest of Teleostei $(23.880597 \%)$ items. This species presented high diversity of food items and Crustacea was the main category ( $\mathrm{IAi}=0.836622)$. Teleostei $(0.154072)$, Mollusca (0.008634), and Sediment (0.000692) were accessory categories, and Teleostei had the highest index (Table 1).

$P$. corvinaeformis: the highest frequency of occurrence was Dendrobranchiata $(36.538462 \%)$, followed by rest of Teleostei (32.692305\%). Fourteen food items were described, and Crustacea represented the main food category ( $\mathrm{IAi}=0.512109)$; Teleostei and Mollusca had the highest values of IAi $(0.171408$ and 0.153332 , respectively) compared to other accessory categories (Animal matters, Sediment, Polychaeta, Insecta, Echinodermata and Algae) (Table 1).

$S$. testudineus showed the least diversity of food items $(\mathrm{n}=8)$. Bivalvia represented the highest frequency of occurrence $(100 \%)$, followed by Clypeasteroida (Echinodermata category) (50\%). Regarding the IAi, Mollusca was the main food category (0.779386). Echinodermata, Sediment, Teleostei, Non-identified items, Vegetal matters, and Crustacea were accessory categories (Table 1). 
Table 1. Alimentary Index (IAi) of food items found in the stomach contents of six fish species discarded by trawl in northeastern Brazil from January to December 2012.

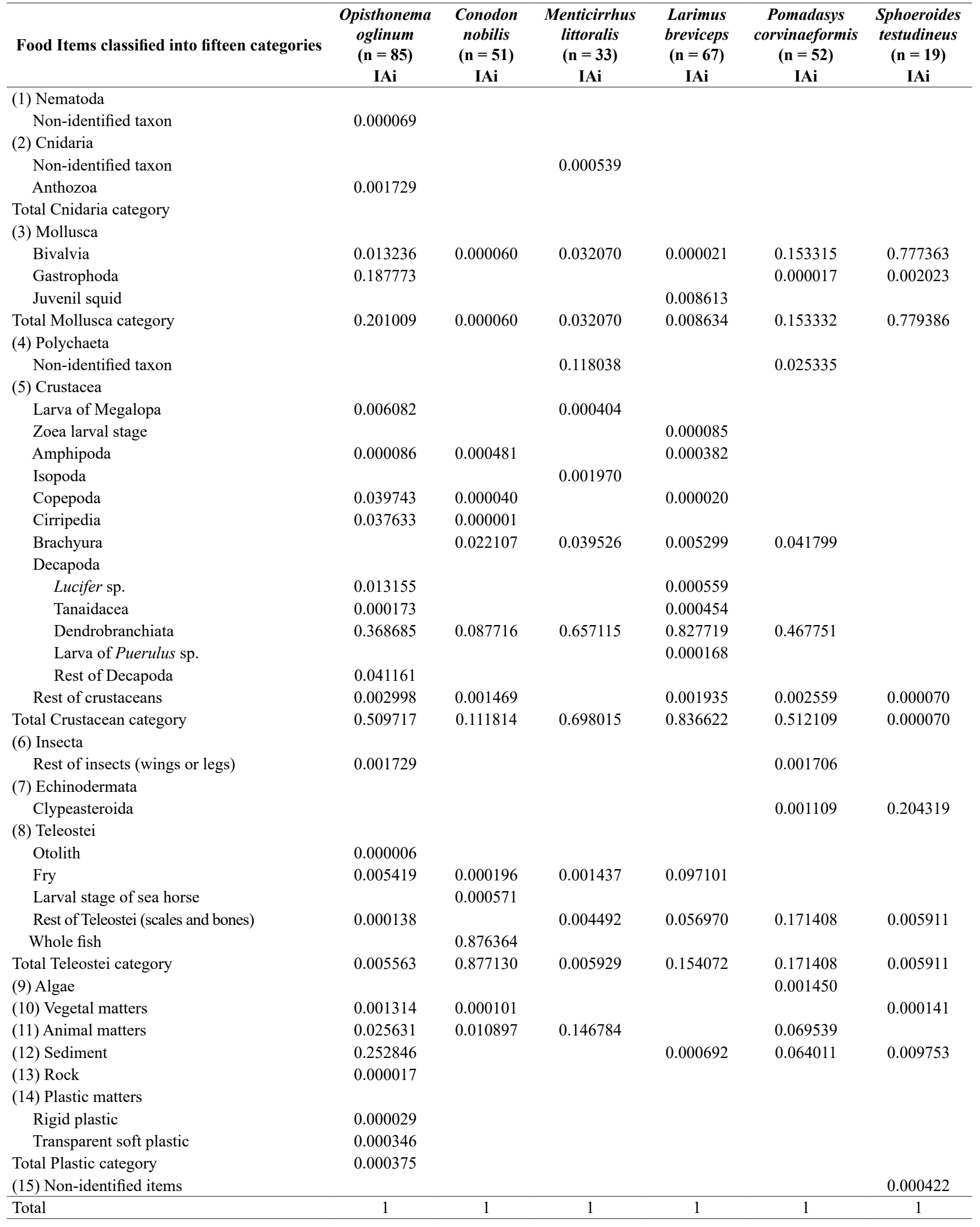


BOMFIM, A.C. et al.

Our results revealed that the species studied are considered carnivorous. O. oglinum, L. breviceps, $M$. littoralis and P. corvinaeformis show a tendency to carcinophagia; $C$. nobilis has tendency to piscivoria, and $S$. testudineus feeds mainly on bivalves.

\section{Feeding and reproductive activities}

According to precipitation data, the dry season occurred from August to December (rain mean $=0.14 \mathrm{~mm}$ ), and the rainy season was from January to July (rain mean $=0.97 \mathrm{~mm}$ ). The SRI analysis revealed that the species studied had higher feeding activity during the dry season; $C$. nobilis had highest SRI $(2.46 \pm 2.32)$, followed by $O$. oglinum $(2.39 \pm 1.27)$. On the other hand, the GSI was higher in the rainy season, and $S$. testudineus presented the highest GSI $(3.04 \pm 3.60)$ (Table 2).

\section{Histological features of digestive tube}

We described histological features in four species that represented each group.

O. oglinum: esophagus has concentric tissue layers of mucosa, submucosa, muscular, and serosa. We observed a transition from stratified epithelium (Figure 3a) to a simple columnar epithelium between esophagus and stomach. Stomach mucosa presents folds of the epithelium in the lamina propria forming the gastric pits. We observed numerous tubular gastric glands near the pylorus region (Figure $3 b$ ). Tunica muscular has two layers: external (longitudinal) and internal (circular) (Figure 3c). The pyloric region has strong muscular walls, with a developed muscular layer (Figure 3b). Intestine walls are supplied from mucosa, muscular, and serosa layers (Figure 3d). The epithelium contains cylindrical cells (for absorption) and mucosal cells with goblet-shape.

Table 2. Mean and Standard Deviation of the Stomach Repletion Index (SRI) and Gonadosomatic Index (GSI) of six fish species discarded by trawl in northeastern Brazil, from January to December 2012, according to rainy and dry seasons.

\begin{tabular}{lcccc}
\hline \multirow{2}{*}{ Species } & \multicolumn{2}{c}{ Rainy season } & \multicolumn{2}{c}{ Dry season } \\
& SRI & GSI & SRI & $0.10 \pm 0.05$ \\
Opisthonema oglinum & $2.06 \pm 0.88$ & $0.43 \pm 0.65$ & $2.39 \pm 1.27$ & $0.09 \pm 0.08$ \\
Conodon nobilis & $2.07 \pm 2.21$ & $0.26 \pm 0.14$ & $2.46 \pm 2.32$ & $0.21 \pm 0.16$ \\
Menticirrhus littoralis & $1.28 \pm 0.55$ & $0.67 \pm 0.78$ & $1.78 \pm 1.61$ & $0.59 \pm 0.76$ \\
Larimus breviceps & $0.74 \pm 0.58$ & $0.82 \pm 1.20$ & $1.89 \pm 2.29$ & $0.27 \pm 0.64$ \\
Pomadasys corvinaeformis & $0.88 \pm 0.63$ & $0.73 \pm 0.89$ & $1.16 \pm 1.02$ & $1.88 \pm 1.72$ \\
Sphoeroides testudineus & $1.25 \pm 2.77$ & $3.04 \pm 3.60$ & $1.55 \pm 1.13$ & \\
\hline
\end{tabular}

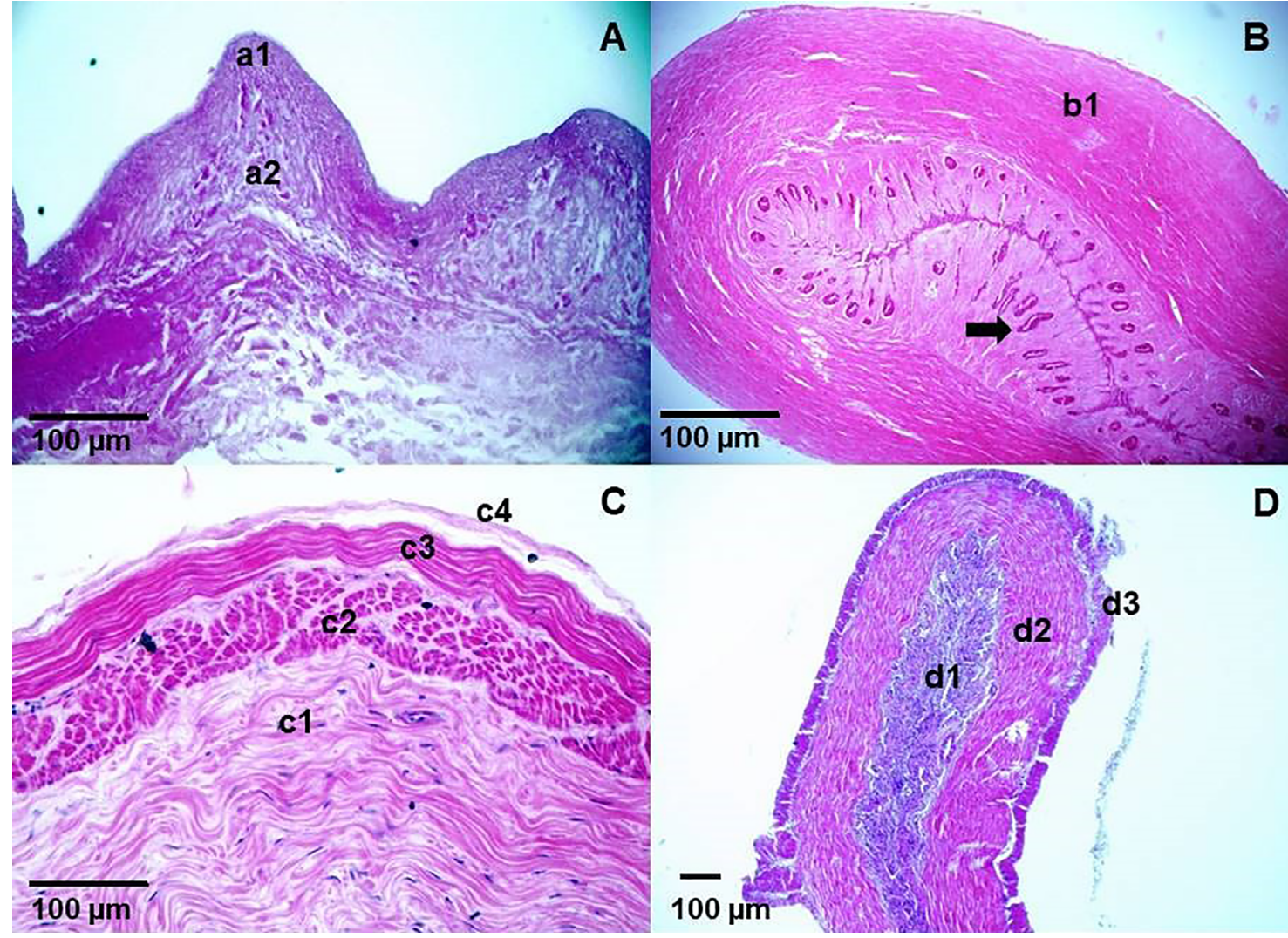

Figure 3. Histological section of digestive tube of Opisthonema oglinum. (A) Esophagus: stratified epithelium (a1) and lamina propria (a2). (B) Pyloric region of the stomach: muscular layer (b1) and tubular gastric glands (arrow). (C) Cardia region of stomach: lamina propria (c1); muscular layer: inner circular layer (c2) and outer longitudinal layer (c3); serosa layer (c4). (D) Small intestine: microvilli (d1); muscular layer (d2); serosa layer (d3). H.E. Bar $100 \mu \mathrm{m}$. 
C. nobilis: esophagus with stratified epithelium (Figure 4a), and lamina propria formed by aglandular connective tissue. In the stomach and intestine, we observed a simple columnar epithelium. Stomach tunica muscular has an outer longitudinal and an inner circular layer, thinner than the layers in esophagus (Figure 4b). The intestine presents many villous structures (Figure 4c), thicker inner circular musculature, and serosa layer similar to the anterior portions of the digestive tube (Figure 4d).

L. breviceps: epithelium of digestive tube has features similar to those found in C. nobilis. We observed basophilic basal cells and mucus-secreting cells in the esophageal epithelium (not stained by hematoxilin-eosin) (Figure 5a). In the transition from esophagus to stomach, we noted a gradual increase in mucus-secreting cells. In the cardia region, walls were thick and reduced light, due to the large number of folds (Figure 5b), and tunica muscular with inner circular and outer longitudinal layers (Figure 5c). Gastric glands were found in the cecal mucosa from invaginations of the simple columnar epithelium (Figure 5d), and they secrete hydrochloric acid and pepsinogen. Intestine tunica muscular has thicker inner circular layer than outer longitudinal (Figure 5e). The pyloric caecum presented features similar to those in the intestine, but a thinner musculature (Figure 5f).

S. testudineus: the histological analysis revealed a pseudo-stomach characterized by less villi and thicker muscular tunica than intestine (Figure 6a, b, c, d), and absence of pyloric caeca. The division between the pseudo-stomach and intestine was evident only through microscopic examination.

\section{Discussion}

The relative abundance of Opisthonema oglinum, Conodon nobilis, Larimus breviceps and Sphoeroides testudineus was higher than the amount obtained by Feitosa et al. (2013) in the same site and considering bycatch. A previous study revealed that Pomadasys corvinaeformis, Menticirrhus littoralis and L. breviceps were negatively related to the fishing activity and the species were more vulnerable to shrimping trawl nets. On the other hand, Pellona harroweri individuals were captured after reaching the maturity size (Bomfim et al. 2019). Feitosa et al. (2013) also observed the impact of trawl nets to the species analyzed, and $C$. nobilis and L. breviceps were classified as less susceptible. Pomadasys corvinaeformis negatively related to fishing activity, despite the higher correlation with the survival criterion.

Sand beaches are considered feeding sites for several fish species, especially for the juvenile individuals (Suda et al. 2002). Our study site includes localities with high shrimp trawl activities, according to data from UNIDADEDE OPERAÇÃODEEXPLORAÇÃOEPRODUÇÃODORIO GRANDE DO NORTE E CEARÁ - UO-RNCE (2012). Our results showed that shrimp had significant importance in the food composition of the fishes examined, once we found the penaeid post-larvae stage in stomach contents.

Diet composition of examined $O$. oglinum was based on Gastrophoda, Dendrobranchiata, Sediment and Cirripedia, with Crustacea as the main category. Vega-Cendejas et al. (1997) found that diet of $O$. oglinum in the Mexico Gulf was mainly composed of benthonic microcrustaceans and macrophyts. The most species classified in the order Clupeiformes are plankton-eating fishes, filtering water and retaining food items (Alves \& Sawaya 1974, Nelson 2006).

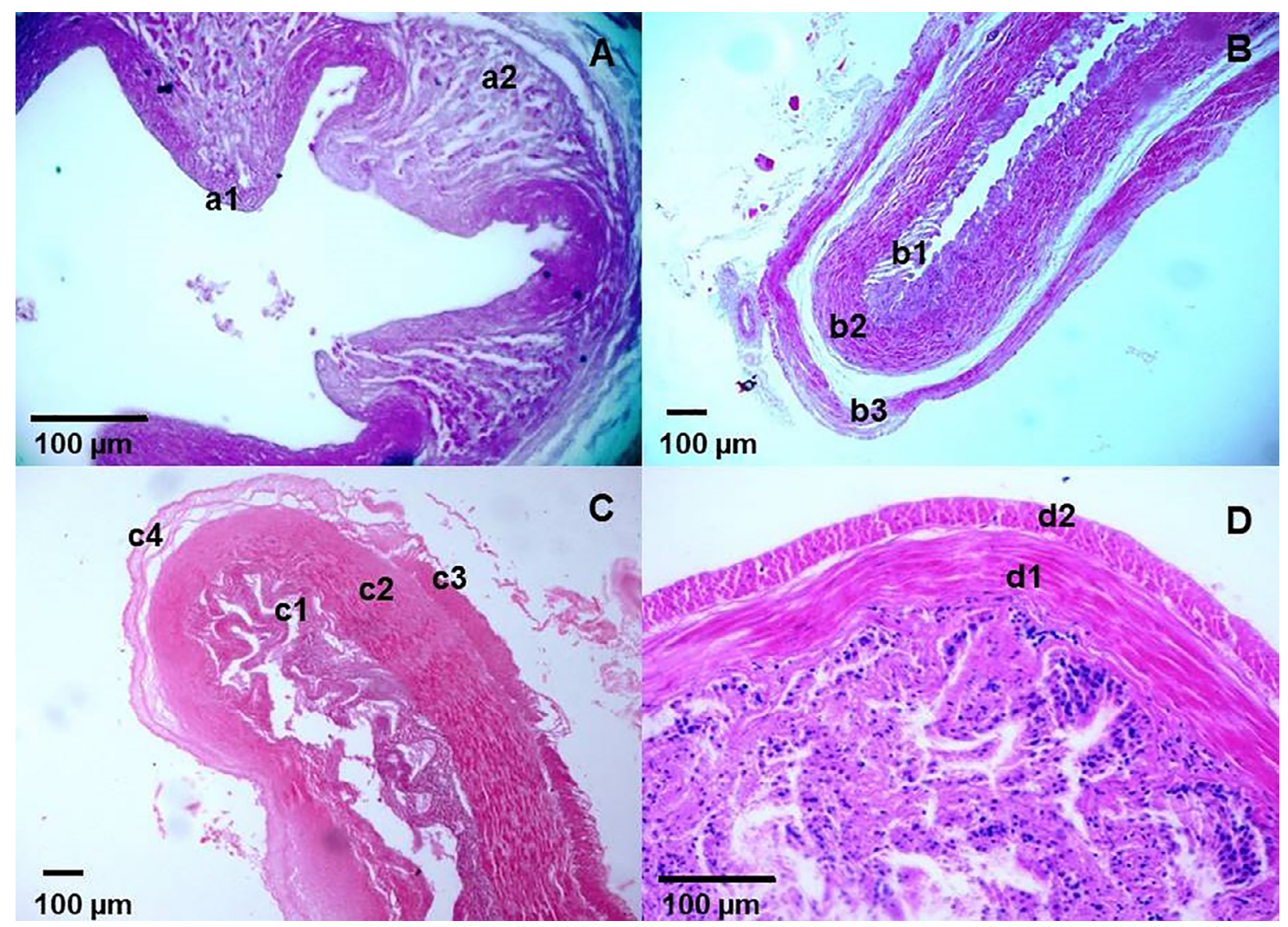

Figure 4. Histological section of digestive tube of Conodon nobilis. (A) Esophagus: stratified epithelium (a1) and lamina propria (a2). (B) Pyloric region of the stomach: folds in the mucosa layer (b1); muscular layer - inner circular layer (b2) and outer longitudinal layer (b3). (C) Small intestine: microvilli (c1); muscular layer - inner circular layer (c2) and outer longitudinal muscle layer (c3); serosa layer (c4). (D) Pyloric caecum: muscular layer - inner circular layer (d1) and outer longitudinal layer (d2). H.E. Bar $100 \mu \mathrm{m}$. 


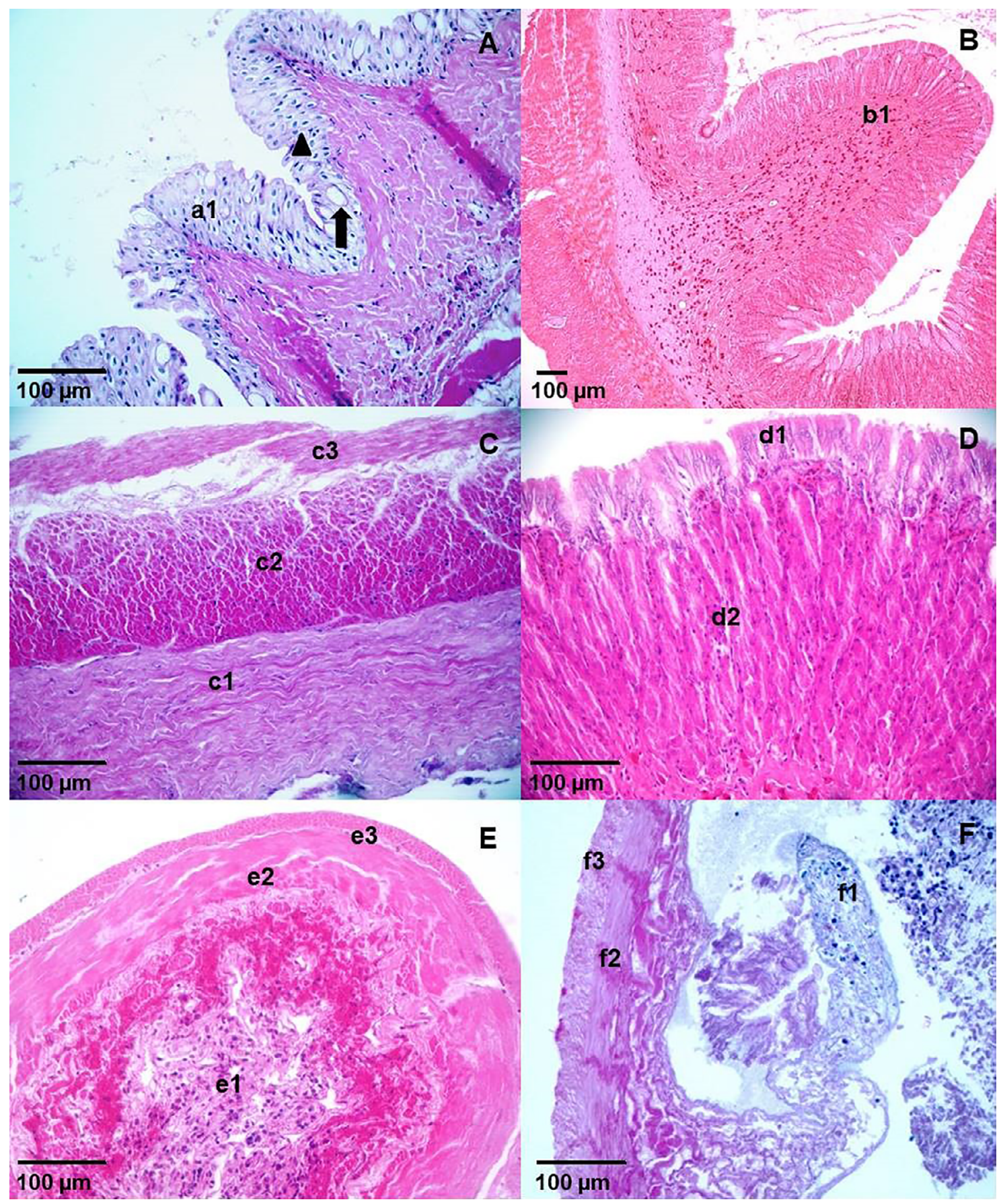

Figure 5. Histological section of digestive tube of Larimus breviceps. (A) Esophagus: simple columnar epithelium (a1), basophilic basal cells (arrowhead) and mucus-secreting cells basal cells (arrow). (B) Cardia region of the stomach: folds (b1). (C) muscular layer - inner circular layer (c1) and outer longitudinal layer (c2); and vascularized serosa layer (c3). (D) Cecal mucosa of the stomach: simple columnar epithelium (d1) and gastric glands (d2). (E) Small intestine: microvilli (e1); muscular layer - inner circular layer (e2) and outer longitudinal layer (e3). (F) Pyloric caecum: microvilli (f1); muscular layer - inner circular layer (f2) and outer longitudinal muscle layer (f3). H.E. Bar $100 \mu \mathrm{m}$.

However, $O$. oglinum seems to be an opportunistic species presenting trophic adaptability according to most food items available in different seasons and types of marine habitat (Wootton 1990). The opportunistic feeding behavior was already described for many fish species in estuaries (Elliot et al. 2007).
In our study site, $C$. nobilis has tendency to piscivory and we identified 13 food items in the stomach contents, as described previously in a study carried out in Jaguaribe beach, Brazil, which reported Decapoda as the main food category (Lopes \& Oliveira-Silva 1999). We considered Teleostei scales as accidental ingestion without indicating a lepidophagic habit. 


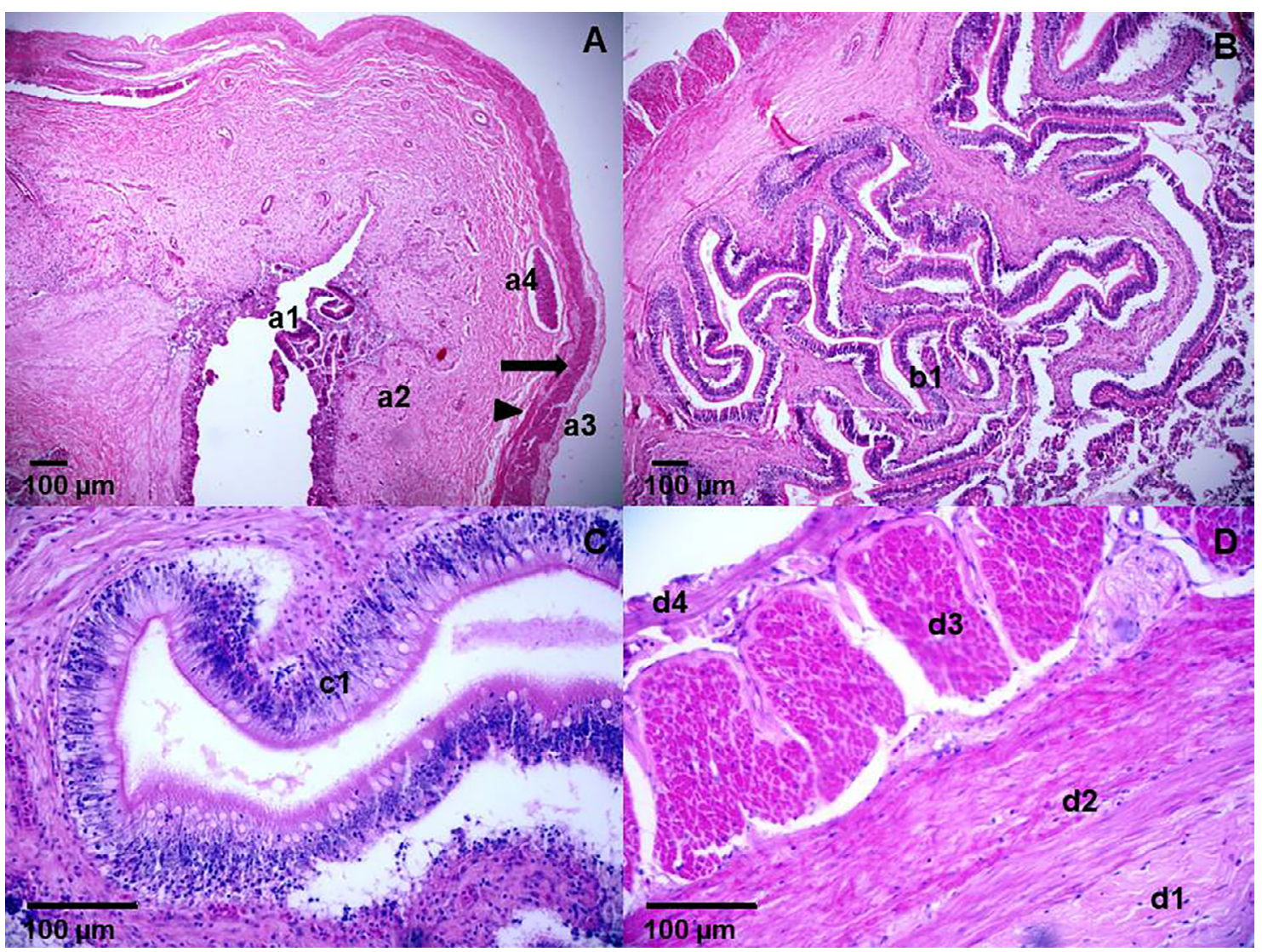

Figure 6. Histological section of digestive tube of Sphoeroides testudineus. (A) Pseudo-stomach: microvilli (a1); muscular layer of mucosa (a2) - inner circular layer (arrowhead) and outer longitudinal layer (arrow); serosa layer (a3); blood vessel (a4). (B, C and D) Small intestine: microvilli (b1); simple cylindrical epithelium (c1); submucosa layer (d1); muscular layer of mucosa - inner circular layer (d2) and outer circular layer (d3); serosa layer (d4). H.E. Bar $100 \mu \mathrm{m}$.

Menticirrhus littoralis ate mainly Dendrobranchiata, followed by Polychaeta. Similar findings were described by previous study in southeastern Brazil with Amphipoda, Polychaeta and Dendrobranchiata presenting high occurrence frequency (Rodrigues \& Vieira 2010).

Our analysis revealed that $L$. breviceps feeds mainly on crustaceans in the study site with Sediment considered as accidental ingestion, corroborating previous studies in different Brazilian areas (Ponta da Ilha beach - Bahia State, and Jaguaribe beach - Pernambuco State) (Moraes et al. 2004, Lopes \& Oliveira-Silva 1999). Moraes et al. (2004) indicated algae also as accidental ingestion; however, we did not find this type of food item in our samples.

Our results showed that Crustacean (represented by Brachyura, Dendrobranchiata and rest of crustaceans) was the main food category of $P$. corvinaeformis examined. In Fortaleza, Ceará State - Brazil, the diet composition analysis of this species revealed, in order of importance, crustaceans, polychaetes, fish and algae. In southeastern Brazil, crustaceans comprised five of the nine food categories (nonidentified crustacean fragments, zoea larvae, amphods, copepods and shrimp) (Costa et al. 1995, Denadai et al. 2013).

In the Potiguar basin, diet of $S$. testudineus was mainly composed by bivalves and echinoderms (order Clypeasteroida). A previous study reported bivalves (especially in the juvenile life-stage), Ceratopogonidae larvae, calanoids, gasthropods, ostracods, cyclopoids, decapods, and barnacles as food items (Araújo et al. 2016). The species studied were considered carnivorous and their diet composition, based on benthic, demersal and pelagic animals, can influence their position in the water column as stated by Wootton (1989). Therefore, these fish species may become more susceptible trawl catches.

The Stomach Repletion Index (SRI) varied between the dry and rainy seasons. The dry season presented higher feeding activity (AugustDecember). Seasonal variation can provide information on life cycle of preys or food competition (Zavala-Camin 1996). In our study site, strong winds occurred between September and December, decreasing shrimp trawls activity on the coast, and shrimp may be more available for the fish species examined. In northeastern Brazil, the breeding time for fishes occurs in the rainy season (January-July) (Bennemann et al. 1996), period with higher gonadosomatic index (GSI) and lower SRI for the fish species investigated. During the rainy season, gonads increase, resulting in a mechanical pressure on the digestive tube and a food ingestion decrease (Bennemann et al. 1996, Costa et al. 2005), explaining our results. Furthermore, higher SRI in the dry season suggests that fishes can try to save energy for the breeding time (rainy season).

Morphology of digestive tube can affect the feeding habit and diet plasticity (Gosavi et al. 2019), and our findings confirm the relation between diet composition and digestive tube morphology, considering the histological features (e.g. pyloric caeca and stomach with thick muscular layer) of the fish species examined. The stomach has a varied shape and structure depending on food habits of fishes, and may be absent in some species (Canan et al. 2012). Examined C. nobilis and L. breviceps presented similar structures with other carnivorous fishes, 
such as well-developed pyloric caeca, short intestine and muscular stomach (Alabssawy et al. 2019). We found mucus-secreting cells in the esophageal epithelium of $L$. breviceps, and in the transition from esophagus to stomach, we noted a gradual increase in this type of cells. The mucus hydrates the food and favors its flow up to intestine, protecting the mucosa against mechanical injuries (Silva et al. 2018), which could be caused by ingestion of whole food items, as observed in our analysis of the diet composition. In the samples from $S$. testudineus, we observed a pseudo-stomach with thick muscular layer, probably involved with mechanical digestion of mollusk and echinoderms (food items found during our analysis); however, the division between the esophagus, stomach, and intestine was not evident through macroscopic examination. As previously reported by Alves \& Sawaya (1974), we observed welldeveloped longitudinal and circular tunica in the muscular layer of pyloric region of $O$. oglinum samples, an important feature considering accidental sediment ingestion during capture of benthic animals.

Our Study confirms that the digestive tube of the examined species has morphological adequacy for carnivorous feeding habit, and provides useful information on tissue structures associated to diet composition, which is sometimes insufficiently answered through macroscopical description.

\section{Acknowledgments}

We thank the staff of Projeto Cetáceos da Costa Branca, Universidade do Estado do Rio Grande do Norte (PCCB-UERN), and Giovanna Almeida Santoro for her assistance with the map edition. This study was funded by PETROBRAS, and was approved by the Chico Mendes Institute for Biodiversity Conservation (ICMBio) Ministry of the Environment through the Biodiversity Information and Authorization System (SISBIO) number 13694-6 and Authorization and Information in Biodiversity (ABIO) number 615/2015. Silmara Rossi is a recipient of postdoctoral fellowship by the Postdoctoral National Program - Coordenação de Aperfeiçoamento de Pessoal de Nível Superior (CAPES; process number 88882.306020/2018-01), Structural and Functional Biology Postgraduate Program - Federal University of Rio Grande do Norte.

\section{Author contributions}

Aline da Costa Bomfim: Substantial contribution in the concept and design of the study; contribution to data collection; contribution to data analysis and interpretation; contribution to manuscript preparation; contribution to critical revision, adding intelectual content.

Daniel Solon Dias Farias: Substantial contribution in the concept and design of the study; contribution to data collection; contribution to data analysis and interpretation.

Hamilton Barroso Mourão-Junior: Contribution to manuscript preparation.

Iara Cecília da Costa Morais: Contribution to data collection.

Silmara Rossi: Contribution to data analysis and interpretation; contribution to manuscript preparation; contribution to critical revision, adding intelectual content.

Simone Almeida Gavilan: Substantial contribution in the concept and design of the study; contribution to data collection; contribution to data analysis and interpretation; contribution to manuscript preparation.
Flávio José de Lima Silva: Substantial contribution in the concept and design of the study; contribution to data collection; contribution to data analysis and interpretation; contribution to manuscript preparation.

\section{Conflicts of interest}

The authors declare that they have no conflict of interest related to the publication of this manuscript.

\section{References}

ABELHA, M.C.F., AGOSTINHO, A.A. \& GOULART, E. 2001. Plasticidades tróficas em peixes de água doce. Acta Sci. 23: 425-434.

ALABSSAWY, A.N., KHALAF-ALLAH, H.M.M. \& GAFAR, A.A. 2019. Anatomical and histological adaptations of digestive tract in relation to food and feeding habits of lizardfish, Synodus variegatus (Lacepède, 1803). Egypt J Aquat Res. 45: 159-165.

ALVES, M.I.M. \& SAWAYA, P. 1974. Aspectos do aparelho digestivo e da alimentação de Opisthonema oglinum (LE SUEUR) (PISCES, CLUPEIDAE). Arq. Cienc. Mar. 14: 135-144.

ARAÚJO, P.R.V., COSTA, S.Y.L., DUARTE, M.R.N. \& PESSANHA, A.L.M. 2016. Feeding and spatial distribution of two estuarine puffer fish in a tropical estuary, north-eastern Brazil. J. Mar. Biol. Assoc. U. K. 98: 581-588.

BENNEMANN, S.T., ORSI, M.L. \& SHIBATTA, O.A. 1996. Atividade alimentar das espécies de peixe do Rio Tibagi, relacionada com o desenvolvimento de gordura e das gônadas. Rev. Bras. Zool. 13: 501-512.

BLOCK, B.A., JONSEN, I.D., JORGENSEN, S.J., WINSHIP, A.J., SHAFFER, S.A., BOGRAD, S.J., HAZEN, E.L., FOLEY, D.G., BREED, G.A., HARRISON, A.L., GANONG, J.E., SWITHENBANK, A., CASTLETON, M., DEWAR, H., MATE, B. R., SHILLINGER, G.L., SCHAEFER, K.M., BENSON, S.R., WEISE, M.J., HENRY, R. W. \& COSTA, D.P. 2011. Tracking apex marine predator movements in a dynamic ocean. Nature. 475: 86-90.

BOMFIM, A.C., FARIAS, D.S.D., MORAIS, I.C.C., ROSSI, S., GAVILAN, S.A. \& SILVA, F.J.L. 2019. The impact of shrimp trawl bycatch on fish reproduction in northeastern Brazil. Biota Amazônia. 9: 37-42.

BURGESS, M.G., MCDERMOTT, G.R., OWASHI, B., REEVES, L.E.P., CLAVELLE, T., OVANDO, D., WALLACE, B.P., LEWISON, R.L., GAINES, S.D. \& COSTELLO, C. 2018. Protecting marine mammals, turtles, and birds by rebuilding global fisheries. Science, AAAS. 359:1255-1258.

CACHERA, M., ERNANDE, B., VILLANUEVA, M.C. \& LEFEBVRE, S. 2017. Individual diet variation in a marine fish assemblage: Optimal Foraging Theory, Niche Variation Hypothesis and functional identity. J. Sea Res. 120: 60-71.

CANAN, B., NASCIMENTO, W.S., SILVA, N.B. \& CHELLAPPA, S. 2012. Morphohistology of the Digestive Tract of the Damsel Fish Stegastes fuscus (Osteichthyes: Pomacentridae). Sci. World J. 2012: 1-9.

COSTA, A.P.R., ANDRADE, D.R., JUNIOR, M.V.V. \& SOUZA, G. 2005. Indicadores quantitativos da biologia reprodutiva de fêmeas de piauvermelho no Rio Paraíba do Sul. Pesq. agropec. bras. 40: 789-795.

COSTA, P.S.R., SANTOS, M.A.M., ESPÍNOLA, M.F.A. \& NETO, C.M. 1995. Biologia e Biometria do Coró Pomadasys corvinaeformis (Steindachner) (Teleostei: Pomadasyidae) em Fortaleza, Ceará, Brasil. Arq. Ciên. Mar. 29: 20-27.

DENADAI, M.R., SANTOS, F.B., BESSA, E., FERNANDEZ, W.S., LORCA, L. \& TURRA, A. 2013. Population biology and diet of Pomadasys corvinaeformis (Perciformes: Pomadasyidae) in Caraguatatuba Bay, Southeastern Brazil. Rev. biol. trop. 61: 1947-1954.

DINEEN, C.F. 1951. A comparative study of the food habits of Cottus bairdii and associated species of Salmonidae. Am. Midl. Nat. 46: 640-645.

DUNN, D.R. 1954. The feeding habits of some of the fishes and some members of the bottom fauna of Llyn Tegid (Bala Lake), Merionethshire. J. Anim. Ecol. 23: 224-233. 
ELLIOT, M., WHITFIELD, A., POTTER, I.C., BLABER, S.J.M., CYRUS, D.P., NORDLIE, F.G. \& HARRISON, T.D. 2007. The guild approach to categorizing estuarine fish assemblages: a global review. Fish fish. 8: 241-268.

GOSAVI, S.M., VERMA, C.R., KHARAT, S.S., PISE, M. \& KUMKAR, P. 2019. Structural adequacy of the digestive tract supports dual feeding habit in catfish Pachypterus khavalchor (Siluriformes: Horabagridae). Acta Histochem. 121: 437-449.

HAJISAMAEA, S., CHOUA L.M. \& IBRAHIM, S. 2003. Feeding habits and trophic organization of the fish community in shallow waters of an impacted tropical habitat. Estuar. Coast. Shelf Sci. 58: 89-98.

HELFMAN, G.S., COLLETTE, B.B., FACEY, D.E. \& BOWEN, B.W. 2009. The Diversity of Fishes: Biology, Evolution, and Ecology. Wiley-Blackwell, London.

INSTITUTO BRASILEIRO DO MEIO AMBIENTE E DOS RECURSOS NATURAIS RENOVÁVEIS (IBAMA). 2010. Boletim Estatístico da Pesca Marítima e Estuarina do Nordeste do Brasil. CEPENE, Tamandaré, p. 9-102.

JIMENEZ, J.A., MAIA, L.P., SERRA, J., \& MORAIS, J. 1999. Aeoloan dune migration along the Ceará coast North-Eastern Brazil. Sedimentology. 46: 689-701.

JÚNIOR, J.G., MENDES, L.F., SAMPAIO, C.L.S. \& LINS, J.E. 2010. Biodiversidade marinha da bacia potiguar: Ictiofauna. Rio de Janeiro: Museu Nacional. p. 195.

KAWAKAMI, E. \& VAZZOLER, G. 1980. Método gráfico e estimativa do índice alimentar aplicado no estudo de alimentação de peixes. Bolm. inst. oceanogr. 29: 205-207.

KENNEDY, M. \& FITZMAURICE, P. 1972. Some aspects of the biology of gudgeon Gohio gobio (L.) in Irish waters. J. Fish Biol. 4: 425-440.

KENNELLY, S.J. \& BROADHURST, M. 2002. By-catch begone: changes in the philosophy of fishing technology. Fish fish. 3: 340-355.

LOPES, P.R.D. \& OLIVEIRA-SILVA, J.T. 1999. Notas sobre a alimentação de Larimus breviceps (Cuvier, 1830) (Actinopterygii: Sciaenidae) na praia de Jaguaribe (Ilha de Itamaracá), Pernambuco. Acta biol. leopoldensia. 21: $161-168$

LOWE-MCCONNELL, R.H. 1999. Estudos ecológicos de comunidades de peixes tropicais. EDUSP, São Paulo.

MADDOCK, D.M. \& BURTON, M.P.M. 1999. Gross and histological observations of ovarian development and related condition changes in American Plaice. J. Fish Biol. 53: 928-944.

MENEZES, N.A. \& FIGUEIREDO, J.L. 2000. Manual de peixes marinhos do sudeste do Brasil. IV. Teleostei (5). São Paulo: Museu de Zoologia da Universidade de São Paulo. p. 96.

MORAES, L.E., LOPES, P.R.D. \& OLIVEIRA-SILVA, J.T. 2004. Alimentação de juvenis de Larimus breviceps (Cuvier, 1830) (Pisces: Actinopterygii: Sciaenidae) na praia de Ponta da Ilha, (Ilha de Itaparica, Bahia). Rev. Cienc. Exatas Nat. 6: 246-256.

NELSON, J.S. 2006. Fishes of the world. John Wiley \& Sons, New York.

RODRIGUES, F.L. \& VIEIRA, J.P. 2010. Feeding strategy of Menticirrhus americanus and Menticirrhus littoralis (Perciformes: Sciaenidae) juveniles in a sandy beach surf zone of southern Brazil. Zoologia. 27: 873-880.

ROSECCHI, E. \& NOUAZE, Y. 1987. Comparaison de cinq índices alimentaires utilisés dans I'analyse des contenus stomacaus. Revue des Travaux de I'Institut des Pêches Maritimes. 49: 111-123.
SILVA, N., GURGEL, H. \& SANTANA, M. 2018. Histological aspects of the digestive tube of the sagüiru, Steindachnerina notonota (Miranda Ribeiro, 1937) (Pisces, Curimatidae), of Ceará Mirim River, Rio Grande do Norte, Brasil. B. Inst. Pesca. 31: 1-8.

SILVA-JÚNIOR, C.A.B., ARAÚJO, M.E. \& FEITOSA, C.V. 2013. Sustainability of capture of fish bycatch in the prawn trawling in northeastern Brazil. Neotrop. Ichthyol. 11: 133-142.

STEWART, B.D. \& JONES, G.P. 2001. Associations between the abundance of piscivorous fishes and their prey on coral reefs: implications for prey-fish mortality. Mar biol. 138: 383-397.

STRICTA-PEREIRA, L., AGOSTINHO, A.A. \& GOMES, L.C. 2010. Cage culture with tilapia induces alteration in the diet of natural fish population: the case of Auchenipterus osteomystax. Braz J Biol. 70: 1021-1030.

SOARES, U.M., ROSSETTI, E.L., \& CASSAB, R.C.T. 2003. Bacias sedimentares brasileiras. Bacia Potiguar. Fundação Paleontológica Phoenix. 56: $1-15$.

SUDA, Y., INOUE, T. \& UCHIDA, H. 2002. Fish communities in the surf zone of a protected sandy beach at Doigahama, Yamaguchi Prefecture, Japan. Coast Shelf Sci. 55: 81-96.

SWYNNERTON, G.H. \& WORTHINGTON, E.B. 1940. Notes on the food of fish in Haweswater (Westmorland). J Anim Ecol. 9: 183-187.

SZPILMAN, M. 2000. Peixes Marinhos do Brasil: guia prático de identificação. MAUAD Editora, Rio de Janeiro. p. 288.

TESTA, V. \& BOSENCE, D.W.J. 1999. Physical and biological controls on the formation of carbonate and siliciclastic bedforms on the north-east Brazilian shelf. Sedimentology. 46: 279-301.

UNIDADE DE OPERAÇÕES DE EXPLORAÇÃO E PRODUÇÃO DO RIO GRANDE DO NORTE E CEARÁ - UO-RNCE. Projeto de Monitoramento do Desembarque Pesqueiro Regional da Bacia Potiguar. Natal, RN, 2012.

VEGA-CENDEJAS, M.E., MEXICANO-CÍNTORA, G. \& ARCE, A.M. 1997. Biology of the thread herring Opisthonema oglinum (Pisces: Clupeidae) from a beach seine fishery of the Campeche Bank, Mexico. Fish Res. 30: 117-126.

VIEIRA-LOPES, D.A., PINHEIRO, N.L., SALES, A., VENTURA, A., ARAÚJO, F.G., GOMES, I.D. \& NASCIMENTO, A.A. 2013. Immunohistochemical study of the digestive tract of Oligosarcus hepsetus. World J Gastroentero. 19: 1919-1929.

VITAL, H. 2006. Erosão e progradação do litoral brasileiro. In (D. Muehe, ed.) Rio Grande do Norte. Brasília: MMA. p. 476.

WOLFERT, P.R. \& MILLER, T.J. 1978. Age growth and food of Northern pike in EasternLake Ontario. Trans. Am. Fish. Soc. 107: 696-702.

WOOTTON, R.J. 1989. Feeding. In Ecology of Teleost Fishes. (R.J. Wootton, ed.) Kluwer Academic Publishers, Dordrecht. p. 392.

WOOTTON, R.J. 1990. Ecology of Teleost Fishes. Fish Fisheries Serie I. Chapman and Hall, London, $404 \mathrm{p}$.

WOOTTON, R.J., EVANS, G.W. \& MILLS, L.A. 1978. Annual cycle in female three-spined sticklebacks (Gasterosteus aculeatus L.) from an upland and lowland population. J. Fish Biol. 12: 331-343. 